\title{
Length-weight relationships for 21 coastal fish species of the Azores, north-eastern Atlantic
}

\author{
T. Morato ${ }^{a, *}$, P. Afonso ${ }^{\text {a }}$, P. Lourinho ${ }^{\text {a }}$, J.P. Barreiros ${ }^{\mathrm{b}}$, \\ R.S. Santos ${ }^{\mathrm{a}}$, R.D.M. Nash ${ }^{\mathrm{c}}$ \\ ${ }^{a}$ Departamento de Oceanografia e Pescas, Universidade dos Açores, PT-9901-862 Horta, Portugal \\ ${ }^{\mathrm{b}}$ Departamento de Ciências Agrárias, Universidade dos Açores, PT-9701-851 Angra do Heroísmo, Portugal \\ ${ }^{\mathrm{c} S}$ Shool of Biological Sciences, University of Liverpool, Port Erin Marine Laboratory, Port Erin, Isle of Man IM9 6JA, UK
}

Received 24 January 2000; received in revised form 9 May 2000; accepted 21 May 2000

\begin{abstract}
Length-weight relationships were estimated for 21 coastal fish species of the Azores, namely Abudefduf luridus, Bothus podas, Chromis limbata, Coris julis, Diplodus sargus, Echiichthys vipera, Gaidropsarus guttatus, Labrus bergylta, Mullus surmuletus, Phycis phycis, Pomatomus saltator, Sarda sarda, Scorpaena maderensis, Scorpaena notata, Seriola rivoliana, Serranus atricauda, Sparisoma cretense, Sphyraena viridensis, Synodus saurus, Thalassoma pavo and Trachinotus ovatus. Significant length-weight relationships were found for all species. Sexual dimorphism did not affect the length-weight relationships, except in the cases of $S$. cretense and $C$. julis. Length-length equations for converting size measurements (standard length (SL) and fork length (FL) to total length (TL)) are also presented for all fish species. (C) 2001 Elsevier Science B.V. All rights reserved.
\end{abstract}

Keywords: Length-weight relationships; Length-length relationships; Azores; Coastal fishes

\section{Introduction}

Length and weight data are useful and standard results of fish sampling programs. Such data are essential for a wide number of studies, for example estimating growth rates, age structure, and other aspects of fish population dynamics (Kolher et al., 1995). Length-weight regressions have been extensively used to estimate weight from length because of technical difficulties and the amount of time required to record weight in the field. These relationships are

\footnotetext{
* Corresponding author. Tel.: +351-292-292988; fax: +351-292-292659.

E-mail address: telmo@horta.uac.pt (T. Morato).
}

often used to calculate the standing stock biomass (e.g. Martin-Smith, 1996), condition indices, in the analysis of ontogenetic changes (Safran, 1992) and several other aspects of fish population dynamics. However, estimated growth parameters (length and weight) can deviate substantially from true estimates of the population parameters due to inadequacies in the sampling design (Safran, 1992). For example, because nearly all fishery surveys are focused on commercial or recreational species, the resulting parameters are based on adults and the juvenile phase is often missing from the data sets.

In the Azores, the northern-most archipelago of the Atlantic, coastal fish have been poorly studied and very little biological information is available, includ- 
ing most of the commercially important species. Moreover, there is an urgent need to manage and regulate the small-scale coastal fishery in the region, and this requires basic population dynamics information for the target species (Santos et al., 1995). The present paper describes the length-weight relationships for 21 coastal fish species in the Azores using data collected during a baseline survey aimed to study the coastal fish community of the archipelago. We include the most common and representative coastal species of both soft and hard substrata (Patzner et al., 1991), and also most of the species targeted by local artisanal fisheries: Abudefduf luridus, Bothus podas, Chromis limbata, Coris julis, Diplodus sargus, Echiichthys vipera, Gaidropsarus guttatus, Labrus bergylta, Mullus surmuletus, Phycis phycis, Pomatomus saltator, Sarda sarda, Scorpaena maderensis, Scorpaena notata, Seriola rivoliana, Serranus atricauda, Sparisoma cretense, Sphyraena viridensis, Synodus saurus, Thalassoma pavo and Trachinotus ovatus. With the exception of $P$. phycis (Silva, 1985) and B. podas (Nash et al., 1991), our results constitute the first information for 19 of the 21 species regarding Azorean populations.

\section{Materials and methods}

Length and weight data $(n=6709$, see Table 1$)$ were collected from a number of fish species throughout the

Table 1

Weight-length relationships for 21 coastal fish species from the Azores ${ }^{\mathrm{a}}$

\begin{tabular}{|c|c|c|c|c|c|c|c|c|c|c|c|}
\hline \multirow[t]{2}{*}{ Species } & \multirow[t]{2}{*}{ Sex } & \multicolumn{5}{|c|}{ Length characteristics } & \multicolumn{4}{|c|}{ Parameters of the relationship } & \multirow[t]{2}{*}{$P$} \\
\hline & & $n$ & Mean & S.E. & Minimum & Maximum & $a$ & $b$ & S.E. $(b)$ & $r^{2}$ & \\
\hline \multirow[t]{3}{*}{ A. luridus } & Both & 89 & 10.3 & 0.52 & 2.7 & 17.4 & 0.0344 & 2.813 & 0.064 & 0.956 & \multirow[t]{3}{*}{0.8578} \\
\hline & Males & 32 & 15.1 & 0.33 & 11.9 & 17.4 & 0.0064 & 3.444 & 0.116 & 0.967 & \\
\hline & Females & 16 & 12.8 & 0.48 & 10.3 & 15.8 & 0.0081 & 3.410 & 0.154 & 0.970 & \\
\hline \multirow[t]{3}{*}{ B. podas } & Both & 511 & 10.5 & 0.24 & 2.7 & 23.4 & 0.0082 & 3.124 & 0.014 & 0.991 & \multirow[t]{3}{*}{0.1658} \\
\hline & Males & 136 & 16.0 & 0.22 & 10.6 & 23.4 & 0.0104 & 3.035 & 0.046 & 0.970 & \\
\hline & Females & 65 & 16.6 & 0.35 & 10.2 & 22.1 & 0.0141 & 2.919 & 0.076 & 0.959 & \\
\hline \multirow[t]{3}{*}{ C. limbata } & Both & 147 & 10.7 & 0.33 & 1.8 & 16.4 & 0.0142 & 3.058 & 0.020 & 0.994 & \multirow[t]{3}{*}{0.3030} \\
\hline & Males & 77 & 13.2 & 0.15 & 10.1 & 16.4 & 0.0461 & 2.605 & 0.109 & 0.884 & \\
\hline & Females & 31 & 12.7 & 0.17 & 10.0 & 13.8 & 0.0229 & 2.878 & 0.267 & 0.800 & \\
\hline \multirow[t]{3}{*}{ C. julis } & Both $^{*}$ & 421 & 15.6 & 0.17 & 7.4 & 24.2 & 0.0058 & 3.175 & 0.018 & 0.987 & \multirow[t]{3}{*}{0.0006} \\
\hline & Males & 129 & 19.3 & 0.19 & 10.3 & 24.2 & 0.0049 & 3.242 & 0.063 & 0.954 & \\
\hline & Females & 244 & 14.0 & 0.14 & 8.1 & 20.1 & 0.0087 & 3.011 & 0.030 & 0.977 & \\
\hline \multirow[t]{3}{*}{ D. sargus } & Both & 1178 & 18.2 & 0.33 & 1.7 & 41.1 & 0.0111 & 3.181 & 0.005 & 0.997 & \multirow[t]{3}{*}{0.6155} \\
\hline & Males & 231 & 24.5 & 0.45 & 9.2 & 39.8 & 0.0180 & 3.032 & 0.040 & 0.961 & \\
\hline & Females & 446 & 27.1 & 0.30 & 12.2 & 41.1 & 0.0166 & 3.054 & 0.025 & 0.970 & \\
\hline E. vipera & Both $^{b}$ & 49 & 7.8 & 0.37 & 2.6 & 14.3 & 0.0084 & 3.171 & 0.039 & 0.993 & \\
\hline \multirow[t]{3}{*}{ G. guttatus } & Both & 124 & 20.1 & 0.32 & 12.5 & 32.6 & 0.0052 & 3.141 & 0.063 & 0.953 & \multirow[t]{3}{*}{0.1669} \\
\hline & Males & 15 & 19.4 & 0.57 & 15.7 & 24.1 & 0.0169 & 2.744 & 0.362 & 0.815 & \\
\hline & Females & 95 & 20.5 & 0.39 & 12.5 & 32.6 & 0.0049 & 3.162 & 0.066 & 0.961 & \\
\hline \multirow[t]{3}{*}{ L. bergylta } & Both & 355 & 34.1 & 0.41 & 17.9 & 50.0 & 0.0141 & 3.039 & 0.024 & 0.979 & \multirow[t]{3}{*}{0.1472} \\
\hline & Males & 28 & 41.3 & 1.33 & 20.4 & 49.0 & 0.0197 & 2.929 & 0.066 & 0.974 & \\
\hline & Females & 306 & 33.6 & 0.43 & 17.9 & 50.0 & 0.0126 & 3.074 & 0.026 & 0.978 & \\
\hline \multirow[t]{3}{*}{ M. surmuletus } & Both & 1149 & 14.4 & 0.23 & 4.6 & 34.4 & 0.0069 & 3.219 & 0.008 & 0.992 & \multirow[t]{3}{*}{0.1728} \\
\hline & Males & 90 & 19.6 & 0.33 & 12.8 & 27.2 & 0.0125 & 3.002 & 0.086 & 0.933 & \\
\hline & Females & 374 & 23.0 & 0.27 & 8.5 & 34.4 & 0.0097 & 3.111 & 0.023 & 0.974 & \\
\hline P. phycis & Both $^{b}$ & 42 & 43.3 & 1.54 & 11.1 & 59.5 & 0.0069 & 3.135 & 0.044 & 0.992 & \\
\hline P. saltator & Both & 58 & 42.8 & 3.20 & 8.6 & 91.0 & 0.0091 & 3.012 & 0.019 & 0.998 & 0.5172 \\
\hline
\end{tabular}


Table 1 (Continued)

\begin{tabular}{|c|c|c|c|c|c|c|c|c|c|c|c|}
\hline \multirow[t]{2}{*}{ Species } & \multirow[t]{2}{*}{ Sex } & \multicolumn{5}{|c|}{ Length characteristics } & \multicolumn{4}{|c|}{ Parameters of the relationship } & \multirow[t]{2}{*}{$P$} \\
\hline & & $n$ & Mean & S.E. & Minimum & Maximum & $a$ & $b$ & S.E. $(b)$ & $r^{2}$ & \\
\hline & Males & 14 & 60.2 & 2.89 & 46.3 & 86.0 & 0.0289 & 2.725 & 0.194 & 0.943 & \\
\hline & Females & 22 & 58.4 & 2.80 & 20.1 & 91.0 & 0.0538 & 2.580 & 0.127 & 0.953 & \\
\hline S. sarda & Both $^{\mathrm{b}}$ & 31 & 60.4 & 2.80 & 22.0 & 83.5 & 0.0176 & 2.877 & 0.084 & 0.976 & \\
\hline \multirow[t]{3}{*}{ S. maderensis } & Both & 525 & 11.9 & 0.09 & 5.4 & 17.8 & 0.0140 & 3.065 & 0.024 & 0.969 & 0.0562 \\
\hline & Males & 184 & 13.3 & 0.14 & 8.4 & 17.8 & 0.0161 & 3.013 & 0.056 & 0.941 & \\
\hline & Females & 151 & 11.8 & 0.14 & 6.9 & 15.6 & 0.0230 & 2.863 & 0.053 & 0.951 & \\
\hline \multirow[t]{3}{*}{ S. notata } & Both & 225 & 15.7 & 0.20 & 5.1 & 22.8 & 0.0153 & 3.051 & 0.027 & 0.982 & 0.5764 \\
\hline & Males & 105 & 16.9 & 0.26 & 10.1 & 22.8 & 0.0163 & 3.035 & 0.055 & 0.967 & \\
\hline & Females & 106 & 15.2 & 0.24 & 5.1 & 20.7 & 0.0175 & 2.997 & 0.041 & 0.981 & \\
\hline \multirow[t]{3}{*}{ S. rivoliana } & Both & 101 & 57.4 & 2.32 & 10.5 & 122.8 & 0.0108 & 3.058 & 0.039 & 0.984 & 0.2489 \\
\hline & Males & 35 & 62.1 & 3.30 & 33.0 & 98.0 & 0.0160 & 2.963 & 0.059 & 0.987 & \\
\hline & Females & 55 & 57.6 & 3.48 & 29.0 & 122.8 & 0.0096 & 3.086 & 0.065 & 0.977 & \\
\hline S. atricauda & & 385 & 28.9 & 0.30 & 11.6 & 41.2 & 0.0076 & 3.175 & 0.023 & 0.980 & \\
\hline \multirow[t]{3}{*}{ S. cretense } & Both ${ }^{*}$ & 647 & 34.3 & 0.37 & 3.1 & 52.2 & 0.0107 & 3.129 & 0.010 & 0.994 & 0.0026 \\
\hline & Males & 273 & 26.1 & 0.52 & 16.1 & 52.2 & 0.0127 & 3.079 & 0.019 & 0.990 & \\
\hline & Females & 340 & 34.4 & 0.47 & 12.6 & 49.5 & 0.0095 & 3.162 & 0.019 & 0.988 & \\
\hline \multirow[t]{3}{*}{ S. viridensis } & Both & 125 & 78.5 & 1.58 & 19.7 & 119.0 & 0.0036 & 3.016 & 0.044 & 0.975 & 0.1079 \\
\hline & Males & 35 & 75.2 & 1.72 & 54.5 & 98.0 & 0.0119 & 2.745 & 0.173 & 0.884 & \\
\hline & Females & 66 & 84.8 & 1.72 & 66.3 & 119.0 & 0.0025 & 3.096 & 0.118 & 0.915 & \\
\hline S. saurus & Both $^{b}$ & 40 & 7.4 & 0.48 & 5.4 & 17.8 & 0.0034 & 3.332 & 0.045 & 0.993 & \\
\hline \multirow[t]{3}{*}{ T. pavo } & Both & 292 & 8.8 & 0.23 & 1.7 & 17.9 & 0.0092 & 3.111 & 0.016 & 0.992 & 0.0772 \\
\hline & Males & 42 & 12.3 & 0.43 & 7.6 & 17.9 & 0.0183 & 2.835 & 0.060 & 0.983 & \\
\hline & Females & 82 & 10.6 & 0.24 & 7.5 & 17.1 & 0.0131 & 2.967 & 0.047 & 0.980 & \\
\hline T. ovatus & Both $^{\mathrm{b}}$ & 221 & 8.3 & 0.32 & 2.6 & 36.2 & 0.0122 & 2.832 & 0.021 & 0.988 & \\
\hline
\end{tabular}

* Significant differences $(P<0.05)$ between males and females.

${ }^{a}$ All regressions are highly significant (ANOVA for $\mathrm{H}_{0}: \beta=0$ against $\mathrm{H}_{\mathrm{A}}: \beta \neq 0 ; P<0.001$ ). $n$ is the sample size, mean, standard error, minimum and maximum total length in centimetre, $a$ and $b$ are the parameters of the equation $\left(\mathrm{W}=a \mathrm{TL}^{b}\right)$, where $\mathrm{W}$ is the total weight $(\mathrm{g})$ and TL is the total length $(\mathrm{cm})$, and $r^{2}$ is the coefficient of determination. $P$ is the $P$-value for Student's $t$-test comparing the slopes of the regressions for males and females.

${ }^{\mathrm{b}}$ Sex not recorded.

year from June 1997 to December 1999. Fish were caught by spear fishing, line and hook and SCUBA hand netting at the islands of Corvo, Santa Maria, Faial and Terceira (Fig. 1). Particular effort was made to collect juveniles, which were obtained from a complementary monthly beach seining program undertaken at Porto Pim Bay, Faial.

Fork length (FL), standard length (SL) and total length (TL) were measured to the nearest millimetre. Individual total weight $(W)$ was recorded to the nearest milligram. Weights and lengths were log transformed and the resulting linear relationship fitted by the least squares regression using $W$ as the dependent variable.
The significance of the regression was assessed by analysis of variance (ANOVA) testing the hypothesis $\mathrm{H}_{0}: \beta=0$ against $\mathrm{H}_{\mathrm{A}}: \beta \neq 0$ (Zar, 1996). To test for possible significant differences between sexes $(P<0.05)$ we used Student's $t$-test for comparison of two slopes (Zar, 1996). S. atricauda was excluded from this analysis because it is a simultaneous hermaphrodite. We used analysis of covariance (ANCOVA) to compare more than two slopes (Zar, 1996) when testing for differences in length-weight relationship of fishes caught at Corvo (the northwestern island), Faial and Terceira (central islands), and Santa Maria (south-eastern island). All analyses 


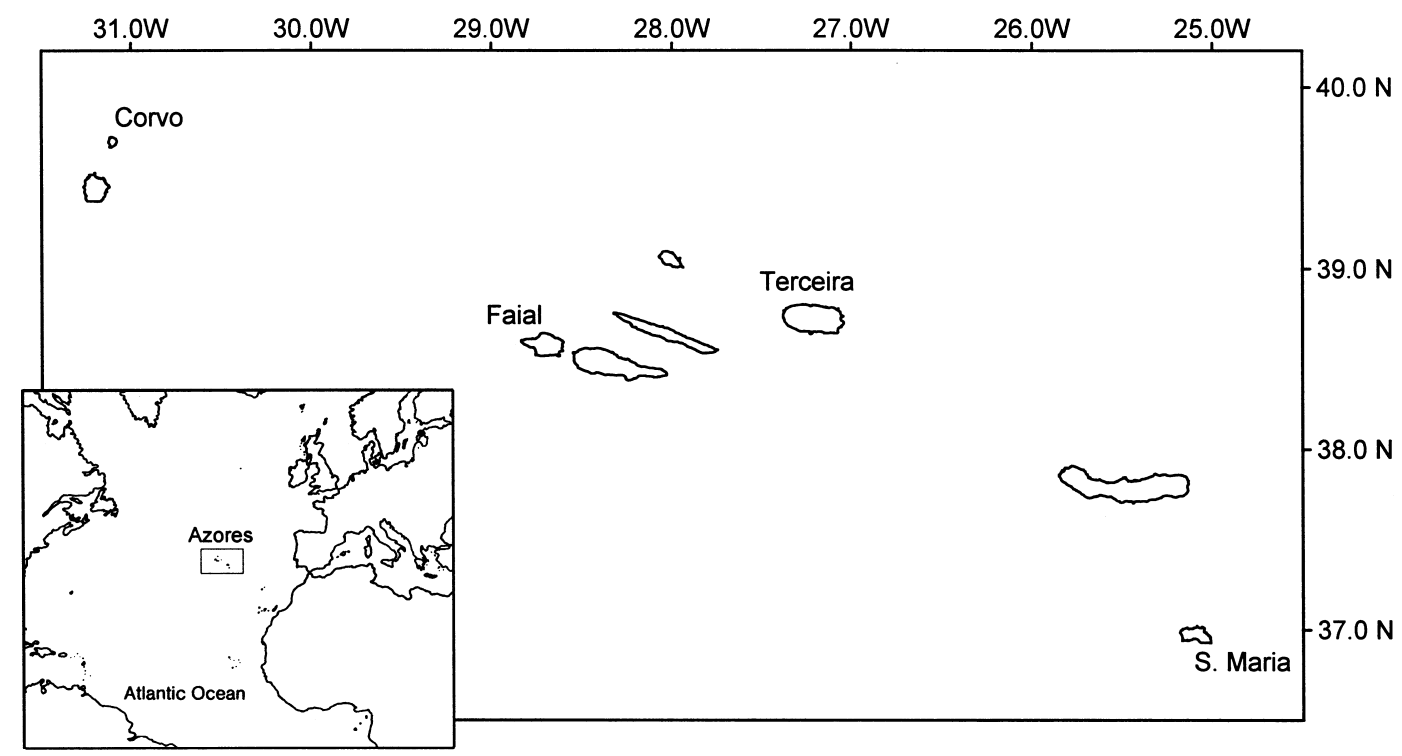

Fig. 1. Location of the Azores archipelago in the north-eastern Atlantic. Sampling was carried out around the islands of Corvo, Santa Maria, Faial and Terceira.

were undertaken using similar size ranges of individuals for each species.

Conversions among length measures can generally be accomplished with simple linear regression models. Therefore, length-length relationships were determined by the method of least squares to fit a simple linear regression model. The significance of the regression was assessed by ANOVA testing the hypothesis $\mathrm{H}_{0}: \beta=0$ against $\mathrm{H}_{\mathrm{A}}: \beta \neq 0$ (Zar, 1996).

\section{Results and discussion}

Length statistics obtained for each species are given, along with the estimated parameters of the length-weight relationship and the coefficient of determination $r^{2}$ (Table 1). Linear regressions were significant for all species $(P<0.001)$, with 43 of $51 r^{2}$ values greater than 0.95 . The other eight $r^{2}$ values were greater than 0.80 . The estimates of the parameter $b$ ranged from 2.58 to 3.44 , with a mean $b$ value of 3.03 $($ S.D. $=0.18)$. Conversions among length measurements are given in Table 2. The length-length regressions were significant $(P<0.001)$ for all species, with all $r^{2}$ values greater than 0.96 .

Pronounced sexual dimorphism in length-weight relationship was observed for $S$. cretense and $C$. julis with significant differences in the slopes of lengthweight relationships between males and females. There were no significant differences in slopes

Table 2

Estimated parameters for the conversion between the length measurements (TL, FL and SL in cm) for 21 coastal species of the Azores ${ }^{\mathrm{a}}$

\begin{tabular}{llllrr}
\hline Species & Equation & $n$ & $r^{2}$ & Constant $a$ & Slope $b$ \\
\hline A. luridus & $\mathrm{TL}=a+b \mathrm{FL}$ & 67 & 0.9960 & 0.0239 & -0.4001 \\
& $\mathrm{TL}=a+b \mathrm{SL}$ & 88 & 0.9925 & -0.1641 & 1.3513 \\
B. podas & $\mathrm{TL}=a+b \mathrm{SL}$ & 508 & 0.9972 & -0.4374 & 1.2775 \\
C. limbata & $\mathrm{TL}=a+b \mathrm{FL}$ & 144 & 0.9880 & -0.3341 & 1.2749 \\
& $\mathrm{TL}=a+b \mathrm{SL}$ & 147 & 0.9898 & 0.2096 & 1.4948 \\
C. julis & $\mathrm{TL}=a+b \mathrm{SL}$ & 421 & 0.9883 & &
\end{tabular}


Table 2 (Continued)

\begin{tabular}{|c|c|c|c|c|c|}
\hline Species & Equation & $n$ & $r^{2}$ & Constant $a$ & Slope $b$ \\
\hline E. vipera & $\mathrm{TL}=a+b \mathrm{SL}$ & 49 & 0.9852 & 0.0298 & 1.2055 \\
\hline D. sargus & $\begin{array}{l}\mathrm{TL}=a+b \mathrm{FL} \\
\mathrm{TL}=a+b \mathrm{SL}\end{array}$ & $\begin{array}{l}1109 \\
1171\end{array}$ & $\begin{array}{l}0.9963 \\
0.9978\end{array}$ & $\begin{array}{l}0.1981 \\
0.2024\end{array}$ & $\begin{array}{l}1.0935 \\
1.2828\end{array}$ \\
\hline G. guttatus & $\mathrm{TL}=a+b \mathrm{SL}$ & 124 & 0.9787 & 0.3408 & 1.1341 \\
\hline L. bergylta & $\mathrm{TL}=a+b \mathrm{SL}$ & 355 & 0.9802 & 0.5802 & 1.2234 \\
\hline M. surmuletus & $\begin{array}{l}\mathrm{TL}=a+b \mathrm{FL} \\
\mathrm{TL}=a+b \mathrm{SL}\end{array}$ & $\begin{array}{l}1126 \\
1142\end{array}$ & $\begin{array}{l}0.9974 \\
0.9964\end{array}$ & $\begin{array}{r}0.0270 \\
-0.0103\end{array}$ & $\begin{array}{l}1.1155 \\
1.2723\end{array}$ \\
\hline P. phycis & $\mathrm{TL}=a+b \mathrm{SL}$ & 42 & 0.9964 & 0.9523 & 1.1231 \\
\hline P. saltator & $\begin{array}{l}\mathrm{TL}=a+b \mathrm{FL} \\
\mathrm{TL}=a+b \mathrm{SL}\end{array}$ & $\begin{array}{l}58 \\
56\end{array}$ & $\begin{array}{l}0.9964 \\
0.9962\end{array}$ & $\begin{array}{r}-0.1873 \\
0.5740\end{array}$ & $\begin{array}{l}1.0975 \\
1.2274\end{array}$ \\
\hline S. sarda & $\begin{array}{l}\mathrm{TL}=a+b \mathrm{FL} \\
\mathrm{TL}=a+b \mathrm{SL}\end{array}$ & $\begin{array}{l}23 \\
31\end{array}$ & $\begin{array}{l}0.9916 \\
0.9917\end{array}$ & $\begin{array}{l}3.3484 \\
4.4716\end{array}$ & $\begin{array}{l}1.0288 \\
1.0936\end{array}$ \\
\hline S. maderensis & $\mathrm{TL}=a+b \mathrm{SL}$ & 525 & 0.9703 & 0.5572 & 1.1992 \\
\hline S. notata & $\mathrm{TL}=a+b \mathrm{SL}$ & 225 & 0.9851 & 0.0305 & 1.3058 \\
\hline S. rivoliana & $\begin{array}{l}\mathrm{TL}=a+b \mathrm{FL} \\
\mathrm{TL}=a+b \mathrm{SL}\end{array}$ & $\begin{array}{r}33 \\
101\end{array}$ & $\begin{array}{l}0.9971 \\
0.9741\end{array}$ & $\begin{array}{l}0.3970 \\
4.4872\end{array}$ & $\begin{array}{l}1.1090 \\
1.1477\end{array}$ \\
\hline S. atricauda & $\mathrm{TL}=a+b \mathrm{SL}$ & 381 & 0.9863 & 0.7592 & 1.1686 \\
\hline S. cretense & $\mathrm{TL}=a+b \mathrm{SL}$ & 639 & 0.9902 & 0.1756 & 1.2439 \\
\hline S. viridensis & $\begin{array}{l}\mathrm{TL}=a+b \mathrm{FL} \\
\mathrm{TL}=a+b \mathrm{SL}\end{array}$ & $\begin{array}{r}44 \\
125\end{array}$ & $\begin{array}{l}0.9614 \\
0.9767\end{array}$ & $\begin{array}{l}1.0467 \\
2.0862\end{array}$ & $\begin{array}{l}1.0733 \\
1.1437\end{array}$ \\
\hline S. saurus & $\begin{array}{l}\mathrm{TL}=a+b \mathrm{FL} \\
\mathrm{TL}=a+b \mathrm{SL}\end{array}$ & $\begin{array}{l}39 \\
40\end{array}$ & $\begin{array}{l}0.9975 \\
0.9932\end{array}$ & $\begin{array}{l}0.0225 \\
0.1821\end{array}$ & $\begin{array}{l}1.0631 \\
1.1284\end{array}$ \\
\hline T. pavo & $\begin{array}{l}\mathrm{TL}=a+b \mathrm{FL} \\
\mathrm{TL}=a+b \mathrm{SL}\end{array}$ & $\begin{array}{l}213 \\
291\end{array}$ & $\begin{array}{l}0.9916 \\
0.9885\end{array}$ & $\begin{array}{l}-0.9687 \\
-0.1065\end{array}$ & $\begin{array}{l}1.1138 \\
1.2724\end{array}$ \\
\hline T. ovatus & $\begin{array}{l}\mathrm{TL}=a+b \mathrm{FL} \\
\mathrm{TL}=a+b \mathrm{SL}\end{array}$ & $\begin{array}{l}219 \\
221\end{array}$ & $\begin{array}{l}0.9960 \\
0.9955\end{array}$ & $\begin{array}{l}-0.4750 \\
-0.3597\end{array}$ & $\begin{array}{l}1.2306 \\
1.3910\end{array}$ \\
\hline
\end{tabular}

${ }^{a}$ All regressions are highly significant (ANOVA for $\mathrm{H}_{0}: \beta=0$ against $\mathrm{H}_{\mathrm{A}}: \beta \neq 0 ; P<0.001$ ), $n$ is the sample size and $r^{2}$ the coefficient of determination.

Table 3

Test for differences in slopes of the length-weight relationship for fish species caught at different islands ${ }^{\mathrm{a}}$

\begin{tabular}{|c|c|c|c|c|c|c|c|c|}
\hline \multirow[t]{2}{*}{ Species } & \multicolumn{2}{|c|}{ Santa Maria } & \multicolumn{2}{|l|}{ Faial } & \multicolumn{2}{|c|}{ Corvo } & \multicolumn{2}{|c|}{ Covariance analysis } \\
\hline & $n$ & $b_{1}$ & $n$ & $b_{2}$ & $n$ & $b_{3}$ & $F$ & $P$ \\
\hline D. sargus & 141 & 3.026 & 537 & 3.067 & 153 & 3.094 & 1.143 & 0.319482 \\
\hline L. bergylta & 39 & 2.959 & 281 & 3.046 & 34 & 2.748 & 2.379 & 0.094175 \\
\hline M. surmuletus & 118 & 3.174 & 1012 & 3.221 & 19 & 3.041 & 1.378 & 0.252559 \\
\hline S. maderensis & 102 & 3.125 & 314 & 3.031 & 109 & 3.004 & 1.150 & 0.317570 \\
\hline S. atricauda & 106 & 3.103 & 247 & 3.134 & 32 & 3.048 & 0.379 & 0.684994 \\
\hline S. cretense & 204 & 3.077 & 321 & 3.201 & 115 & 3.058 & 13.163 & 0.000003 \\
\hline
\end{tabular}

\footnotetext{
${ }^{a} n$ is the sample size, $b$ the regression slope. Covariance analysis for $\mathrm{H}_{0}: \beta_{1}=\beta_{2}=\beta_{3}$.
} 
between males and females in any of the other species.

Significant differences in length-weight relationships between islands were found only for $S$. cretense (Table 3). The observed difference could be due to the sampling procedure, namely sample size and length range. However, the sample of $S$. cretense was relatively large and covered a reasonable size range, suggesting that the differences in slope could reflect the influence of differences in environmental or habitat factors. For example, differences in the water thermal regime are known to influence fish growth (Jobling, 1997). If this is true, differences in lengthweight relationship among different islands could also be expected for the other five species, which does not appear to be the case. However, a conclusive comparative analysis requires information on growth rates and length-at-age in the different sub-samples, as well as data on mean water temperature in the different islands. Furthermore, such analysis should be placed in the broader context of each species distribution range, benefiting from the comparison with similar studies from other geographical areas (e.g. Pérez and Contreras, 1995; Petrakis and Stergiou, 1995; Gonçalves et al., 1997). This aspect does warrant further study.

\section{Acknowledgements}

Financial support was given by the Fundação da Ciência e Tecnologia through the PRAXIS/3/3.2/ EMG/1957/95 project, and PRAXIS grants GGPXXI/BIC/1938/96 to TM and GGPXXI/BIC/ $1930 / 96$ to PA. We wish to thank several volunteers for their help in data collection, namely Jorge Fontes, Miguel Machete, Fernando Tempera, Frederico Cardigos, Octávio Melo, Ana Fernandes, Filipa Gomes, José
Branco, Carmelina Leal, Fátima Mendes, Victor Rosa, Paulo Martins, Noberto Serpa and Marco Rosa.

\section{References}

Gonçalves, J.M.S., Bentes, L., Lino, P.G., Ribeiro, J., Canário, A.V.M., Erzini, K., 1997. Weight-length relationships for selected fish species of the small-scale demersal fisheries of the south and south-west coast of Portugal. Fish. Res. 30, 253-256.

Jobling, M., 1997. Temperature and growth: modulation of growth rate via temperature change. In: Wood, C.M., McDonald, D.G. (Eds.), Global Warming: Implications for Freshwater and Marine Fish. Society for Experimental Biology, Seminar Series No. 61, Cambridge University Press, Cambridge, pp. 225-253.

Kolher, N., Casey, J., Turner, P., 1995. Length-weight relationships for 13 species of sharks from the western North Atlantic. Fish. Bull. 93, 412-418.

Martin-Smith, K.H., 1996. Length/weight relationships of fishes in a diverse tropical freshwater community, Sabah, Malaysia. J. Fish Biol. 49, 731-734.

Nash, R.D.M., Geffen, A.J., Santos, R.S., 1991. The wide-eyed flounder, Bothus podas Delaroche, a singular flatfish in varied shallow-water habitats of the Azores. Neth. J. Sea Res. 27 (3/4), 367-373.

Patzner, R.A., Santos, R.S., Ré, P., Nash, R.D.M., 1991. Littoral fishes of the Azores: an annotated checklist of fishes observed during the 'Expedition Azores 1989'. Arquipélago — Life Earth Sci. 10, 101-111.

Pérez, P.P., Contreras, N.P., 1995. Relaciones talla-peso de peces capturados en las campañas de arrastre demersal, demersales 0993 y demersales 0994. Inf. Téc. Inst. Esp. Oceanogr. 159, 16.

Petrakis, G., Stergiou, K.I., 1995. Weight-length relationships for 33 fish species in Greek waters. Fish. Res. 21, 465-469.

Safran, P., 1992. Theoretical analysis of the weight-length relationships in the juveniles. Mar. Biol. 112, 545-551.

Santos, R.S., Hawkins, S., Monteiro, L.R., Alves, M., Isidro, E.J., 1995. Case studies and reviews. Marine research, resources and conservation in the Azores. Aquat. Conserv.: Mar. Freshwat. Ecosyst. 5, 311-354.

Silva, H.M., 1985. Age and growth of the forkbeard Phycis phycis (L., 1766), in Azorean waters. ICES CM 1985/G:72, 11 pp.

Zar, J.H., 1996. Biostatistical Analysis, 3rd Edition. Prentice-Hall, Englewood Cliffs, NJ, $662 \mathrm{pp}$. 